\title{
PENERAPAN MODEL PEMBELAJARAN APTITUDE TREATMENT INTERACTION (ATI) UNTUK MENINGKATKAN HASIL BELAJAR SISWA PADA MATERI LUAS PERMUKAAN KUBUS DAN BALOK KELAS VIII SMP MARDI PUTERA SURABAYA
}

\author{
Ovy Nuraini ${ }^{1}$, Chusnal Ainy ${ }^{2}$, Endang Suprapti ${ }^{3}$ \\ Program Studi Pendidikan Matematika, FKIP UMSurabaya \\ Mysunovy@yahoo.com
}

\begin{abstract}
ABSTRAK
SMP Mardi Putera Surabaya menentukan nilai Standart Kelulusan Minimal (SKM) sebesar 75 untuk mata pelajaran matematika. Saat ini rata-rata nilai matematika pada beberapa siswa masih di bawah Standart Ketuntasan Minimal (SKM) salah satu faktor yang mempengaruhi yaitu pembelajaran masih terpusat pada guru. Sehingga siswa masih belum memahami konsep matematika secara maksimal Penelitian ini bertujuan untuk memngetahui pengaruh penggunaan Model Pembelajaran Aptitude Treatment Interaction (ATI) terhadap hasil belajar siswa kelas VIII pada pelajaran matematika di SMP Mardi Putera Surabaya, peningkatan hasil belajar pada khususnya. Penelitian ini termasuk dalam jenis Penelitian Tindakan Kelas (PTK) karena dalam penelitian ini dilakukan fase-fase tertentu untuk memperbaiki proses pembelajaran di kelas. Kelas penelitian ini adalah kelas VIII-C. Dari Penelitian ini dapat disimpulkan bahwa Penerapan Model Pembelajaran Aptitude Treatment Interaction (ATI) dapat meningkatkan hasil belajar siswa kelas VIII-C SMP Mardi Putera Surabaya. Terlihat dari rata-rata nilai Ulangan Tengah Semester (UTS) siswa ke Siklus I yang memperoleh rata-rata 78,44 atau meningkat sebesar 15,15\%. siklus I ke siklus II memperoleh rata-rata 79,25 atau meningkat sebesar 1,03\%.
\end{abstract}

Kata Kunci: Aptitude Treatment Interaction (ATI), Hasil Belajar, Model Pembelajaran,

\section{PENDAHULUAN}

Matematika adalah salah satu ilmu yang mempunyai peranan penting dalam berkembangnya ilmu pengetahuan dan teknologi (Eka 2007:1). Penerapan matematika banyak digunakan dalam kehidupan sehari-hari. Belajar Matematika tidak hanya menghafal bagi siswa, tetapi siswa harus benar-benar memahami proses dan dapat menerapkannya.

Masalah utama dalam pendidikan di Indonesia adalah rendahnya hasil belajar murid di sekolah. Hasil belajar yang dimaksud tidak hanya pada aspek kemampuan mengerti metematika sebagai pengetahuan dan kognitif saja, tetapi juga aspek sikap (aptitude) terhadap matematika. (Zulkardi, dalam Eka 2007:1)

Kesulitan siswa dalam belajar matematika salah satunya disebabkan oleh metode yang digunakan guru tidak tepat antara lain seperti metode mengajar yang mendasar diri pada latihan mekanis tidak didasarkan pada pengertian, guru dalam mengajar tidak menggunakan alat peraga yang memungkinkan selama alat indranya 
berfungsi, metode mengajar yang menyebabkan murid pasif, sehingga anak tidak ada aktifitas. (Simanjuntak, dalam eka 2007:3)

Masalah klasik yang selalu muncul adalah keluhan masyarakat bahwa proses pembelajaran matematika disekolah yang masih menggunakan pendekatan tradisional atau mekanistik yakni seorang guru secara aktif mengajar matematika, kemudian memberikan contoh dan latihan, disisi lain siswa berfungsi seperti mesin mereka mendengar, mencatat dan mengerjakan latihan yang diberikan oleh guru tanpa guru ketahui daya tangkap masing-masing anak dalam memahami pelajaran yang diberikan berbeda-beda.

Sejalan dengan hal itu, untuk mengantisipasi masalah tersebut maka perlu dilakukan inovasi strategi pembelajaran misalnya dengan menggunakan metode pembelajaran yang berisikan sejumlah metode/cara yang digunakan dijadikan sebagai perlakuan (Treatment) yang efektif digunakan untuk siswa tertentu sesuai dengan kemampuan (aptitude) siswa yakni model pembelajaran Aptitude Treatment Interaction (ATI).

Aptitude Treatment Interaction (ATI) merupakan sebuah model pembelajaran yang berisikan sejumlah strategi pembelajaran yang efektif digunakan untuk siswa tertentu sesuai dengan karakteristik kemampuannya. Didasari oleh asumsi bahwa optimalisasi prestasi akademik/ hasil belajar dapat dicapai melalui penyesuaian antara pembelajaran (treatment) dengan perbedaan kemampuan (aptitude) siswa. Sejalan dengan pengertian ini Cronbach yang dikutip Syafruddin Nurdin mengemukakan bahwa Aptitude Treatment Interaction (ATI) adalah sebuah pendekatan yang berusaha mencari dan menemukan perlakuan-perlakuan (treatment) yang cocok dengan perbedaan (Aptitude) kemampuan siswa, yaitu perlakuan (treatment) yang secara optimal diterapkan untuk siswa yang berbeda tingkat kemampuannya. Sehingga belajar dengan model ATI akan mampu mengembangkan kemampuan siswa sesuai dengan karakteristiknya masingmasing.

Makna esensial dari model pembelajaran ATI, sebagai berikut: 1) ATI merupakan suatu konsep atau model yang berisikan sejumlah strategi pembelajaran yang efektif digunakan untuk siswa tertentu sesuai dengan perbedaan kemampuannya; 2) Sebagai sebuah kerangka teoritik ATI berasumsi bahwa optimalisasi prestasi akademik/hasil belajar akan tercipta apabila perlakuanperlakuan dalam pembelajaran disesuaikan sedemikian rupa dengan perbedaan 
kemampuan siswa; 3) Terdapat hubungan timbal balik antara prestasi belajar yang dicapai siswa dengan pengaturan kondisi pembelajaran di kelas atau dengan kata lain, prestasi belajar yang diperoleh siswa tergantung bagaimana kondisi pembelajran yang dikembangkan guru di kelas.

Untuk mencapai tujuannya, ATI berupaya menemukan dan memilih sejumlah strategi, pendekatan, metode/cara, kiat yang akan dijadikan sebagai perlakuan yang tepat, yaitu perlakuan yang sesuai dengan perbedaan kemampuan siswa. Dengan demikian, dapat disimpulkan bahwa tujuan utama model pembelajaran ATI adalah terciptanya optimalisasi/peningkatan prestasi belajar, melalui penyesuaian pembelajaran dengan perbedaan kemampuan siswa.

\section{METODE PENELITIAN}

Penelitian ini merupakan jenis penelitian tindakan kelas (PTK). Secara garis besar pelaksanaan tindakan ini dilakukan minimal dua siklus yang setiap siklus meliputi empat tahap yaitu

1. Perencanaan tindakan

a. Menyusun Rencana Pelaksanaan Pembelajaran (RPP), adapun pokok bahasan yang dimaksud pada penelitian ini adalah Luas Permukaan Kubus dan Balok.

b. Menyusun LKS

c. Membuat lembar observasi siswa

d. Membuat soal tes untuk siklus I dan siklus II untuk mengetahui apakah hasil belajar siswa meningkat yang telah divalidasi oleh 3 orang validator.

2. Pelaksanaan tindakan

Melaksanakan proses pembelajaran dengan menggunakan Model Pembelajaran Aptitude Treatment Interaction (ATI)

3. Observasi

Melakukan pengamatan terhadap siswa selama proses belajar mengajar berlangsung.

4. Refleksi.

Mengevaluasi hasil pengamatan, kemudian mempersiapkan untuk melaksanakan tindakan selanjutnya 
Penelitian ini dilaksanakan di SMP Mardi Putera J1. Pacar Kembang IV/2 - 4 6 Surabaya. Penelitian ini dilaksanakan pada semester genap tahun ajaran 2014 2015 dilaksanakan pada tanggal 6 - 18 April 2015. Subjek dalam penelitian ini adalah siswa kelas VIII-C SMP Mardi Putera Surabaya. Jumlah siswa kelas VIII $\mathrm{C}$ adalah 25 siswa. Penelitian ini akan dilakukan dalam dua siklus. Setiap siklus dilaksanakan sesuai indikator yang ingin dicapai. Adapun alur skema Penelitian Tindakan Kelas (Arikunto. 2008 : 16) sebagai berikut:

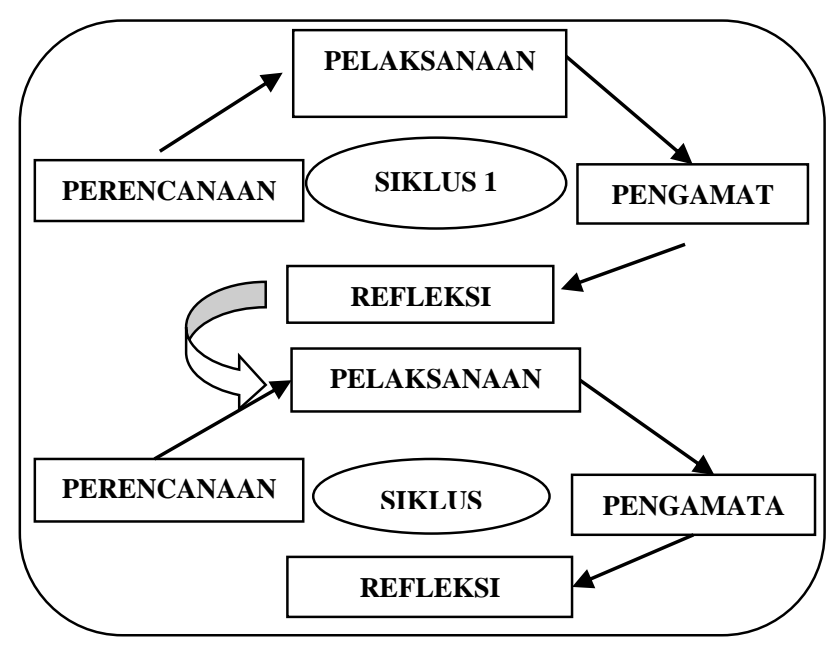

Menurut Arikunto (2010:138) secara utuh, tindakan yang diterapkan dalam penelitian tindakan kelas seperti yang digambarkan dalam bagan melalui tahapan sebagai berikut:

1. Tahap penyusunan rancangan tindakan atau perencanaa

2. Tahap Pelaksanaan Tindakan

3. Tahap Observasi

4. Refleksi

Adapun rancangan dan langkah-langkah penelitian secara terperinci diuraikan sebagai berikut :

\section{Siklus I}

1. Tahap Perencanaan Tindakan

a. Melakukan Observasi awal pada kelas yang akan diteliti

b. Menyusun perangkat pembelajaran berupa Rencana Pelaksanaan Pembelajaran (RPP) dan lembar kerja siswa (LKS)

c. Menyiapkan alat dan bahan yang diperlukan

d. Membuat evaluasi 
e. Membuat Lembar Observasi

f. Mengelompokkan siswa berdasarkan kemampuannya yang dilihat dari hasil UTS (Terlampir).

2. Tahap Pelaksanaan Tindakan

Tahap ini adalah tahap pelaksanaan dalam proses pembelajaran sesuai dengan RPP model pembelajaran ATI yang telah dibuat.

3. Tahap Observasi dan Evaluasi

Pada tahap ini dilaksanakan proses observasi terhadap pelaksanaan tindakan siklus I dengan menggunakan lembar observasi yang telah dibuat kemudian melaksanakan evaluasi dengan menggunakan tes akhir siklus I.

4. Tahap refleksi

Refleksi dilakukan pada setiap akhir siklus I. Hasil observasi dan hasil belajar yang didapat dari siklus I akan dianalisis. Hasil analisis siklus I ini yang akan dijadikan acuan untuk melaksanakan siklus II.

Untuk siklus II dilakukan jika dalam pelaksanaan siklus I dianggap belum mencapai hasil yang maksimal dan teknik yang digunakan sama dengan siklus I dengan merubah atau menyesuaikan kebutuhan siklus II.

\section{Siklus II}

1. Tahap Perencanaan Tindakan

a. Melakukan Observasi awal pada kelas yang akan diteliti

b. Menyusun perangkat pembelajaran berupa Rencana Pelaksanaan Pembelajaran (RPP) dan lembar kerja siswa (LKS)

c. Menyiapkan alat dan bahan yang diperlukan

d. Membuat evaluasi

e. Membuat lembar observasi yang dipakai selama proses pembelajaran.

2. Tahap Pelaksanaan Tindakan

Tahap ini adalah tahap pelaksanaan dalam proses pembelajaran sesuai dengan RPP model pembelajaran ATI yang telah dibuat.

3. Tahap Observasi dan Evaluasi

Pada tahap ini dilaksanakan proses observasi terhadap pelaksanaan tindakan siklus II dengan menggunakan lembar observasi yang telah dibuat kemudian melaksanakan evaluasi dengan menggunakan tes akhir siklus II. 
4. Tahap refleksi

Refleksi dilakukan pada akhir siklus II. Hasil observasi dan hasil belajar yang didapat dari siklus II akan dianalisis.

Metode yang digunakan untuk mengumpulkan data adalah sebagai berikut: pertama adalah metode tes ini merupakan cara untuk mendapatkan nilai setelah siswa melaksanakan proses pembelajaran. Tes yang digunakan adalah tes tulis sebanyak 4 soal, tes siklus 1 diberikan dihari berikutnya setelah pembelajaran pada siklus 1 dilaksanakan dan 4 soal tes siklus 2 diberikan dihari berikutnya setelah pembelajaran pada siklus 2 dilaksanakan. Kedua adalah metode pengamatan (Observasi) Selama proses pembelajaran berlangsung, pengamat melakukan pengamatan (observasi) dengan menggunakan lembar observasi untuk kondisi kelas selama proses pembelajaran berlangsung yaitu Lembar observasi aktivitas siswa. Lembar observasi aktivitas siswa ini dapat digunakan untuk mengetahui aktivitas apa saja yang dilakukan siswa selama proses pembelajaran berlangsung. Ketiga adalah Angket digunakan untuk mengetahui respon masing-masing siswa.

Setelah data-data yang diperlukan terkumpul maka diadakan analisis data dengan tujuan agar dapat menarik kesimpulan ada tidaknya peningkatan hasil belajar siswa pada materi luas permukaan kubus dan balok dengan model pembelajaran aptitude treatment interaction (ATI).

1. Analisis Data Observasi

Analisis data observasi diperoleh dari hasil pengamatan yang dilakukan observer dengan mengisi lembar observasi saat mengamati proses pembelajaran pada setiap siklus. Analisis data observasi digunakan rumus

Keterangan :

$$
p=\frac{f}{N} \times 100 \%
$$

Arikunto, (2010:234)
$\mathrm{p} \quad$ : angka persentase
f : jumlah skor yang dipersentasekan
$\mathrm{N}$ : jumlah skor maksimal semua komponen yang diambil

Untuk mengetahui hasil perhitungan persentase mengenai aktivitas siswa selama proses pembelajaran materi luas permukaan kubus dan balok dengan menggunakan model pembelajaran aptitude treatment interaction (ATI), maka ditentukan angka persentasenya adalah sebagai berikut: 


\begin{tabular}{|c|c|}
\hline Persentase Skor & Kriteria \\
\hline $\mathbf{8 1 \%}-\mathbf{1 0 0 \%}$ & Sangat Baik \\
\hline $\mathbf{6 1 \%}-\mathbf{8 0 \%}$ & Baik \\
\hline $\mathbf{4 1 \%}-\mathbf{6 0 \%}$ & Cukup \\
\hline $\mathbf{2 1 \%}-\mathbf{4 0 \%}$ & Kurang \\
\hline $\mathbf{0 \%}-\mathbf{2 0 \%}$ & Sangat Kurang \\
\hline
\end{tabular}

2. Analisis Data Hasil Belajar Siswa

Penelitian menjumlahkan nilai yang diperoleh siswa dibagi dengan jumlah siswa kelas tersebut sehingga diperoleh nilai rata-rata. Nilai rata-rata didapat dengan menggunakan rumus

$$
\bar{x}=\frac{\sum x}{N}
$$

Achmad (2013:46)

Keterangan:

$\bar{x}=$ nilai rata-rata

$\sum x=$ jumlah nilai seluruh siswa dalam 1 kelas

$\mathrm{N}=$ jumlah seluruh siswa

3. Analisis data untuk prestasi belajar digunakan tingkat penguasaan

$$
T p=\frac{\text { skor aktual }}{\text { skor maksimal ideal }} \times 100 \% \quad \text { Arikunto }(2008: 236)
$$

Keterangan :

Tp $=$ Tingkat Penguasaan

4. Analisis data untuk pengamatan aktifitas siswa dan guru dengan teknik prosentasi

$$
T P=\frac{n(A)}{n(A S)} \times 100 \% \text { Roini }(2011: 43)
$$

Keterangan :

$\mathrm{TP}=$ Prosentasi aktifitas siswa

$\mathrm{n}(\mathrm{A})=$ jumlah aktifitas yang muncul

$\mathrm{n}(\mathrm{AS})=$ jumlah aktifitas keseluruhan

5. Analisis data untuk mengetahui niilai peningkatan prestasi belajar siswa

$$
\text { Peningkatan Prestasi }=\frac{x_{2}-x_{1}}{x_{1}} \times 100 \%
$$

Roini (2011:43)

Keterangan :

$x_{1}=$ rata-rata nilai pertama

$x_{2}=$ rata-rata nilai kedua 
6. Analisis data untuk respon siswa pada saat PBM

Data respon siswa digunakan sebagai data pendukung. Respon siswa secara deskriptif yang dinyatakan dengan persentase untuk tiap aspek yang dihitung menggunakan rumus :

Peningkatan Prestasi $=\frac{A}{B} \times 100 \% \quad$ Roini $(2011: 43)$

Keterangan :

$\mathrm{A}=$ jumlah siswa yang memberi respon

$\mathrm{B}=$ jumlah siswa seluruhnya

\section{HASIL PENELITIAN DAN PEMBAHASAN}

\section{Hasil Penelitian}

Pada Bab III telah dijelaskan bahwa penelitian ini adalah penelitian tindakan kelas (PTK). Penelitian ini dilaksanakan di SMP Mardi Putera Surabaya di kelas VIII-C, jumlah seluruh siswanya adalah 25 siswa. penelitian ini terdiri dari 4 tahap yaitu perencaan, pelaksanaan, pengamatan dan refleksi. Penelitian ini dilakukan pada tanggal 6-18 april 2015. Pokok bahasan yang dipelajari adalah Luas Permukaan Kubus dan Balok.

Setelah dilakukan penelitian diperoleh data hasil pengamatan aktivitas siswa, data sebelum tindakan dan data setelah tindakan atau hasil tes akhir siswa dan angket respon siswa. Data sebelum penelitian diperoleh dari hasil Ulangan Tengah Semester (UTS) yang didapat dari guru mata pelajaran matematika. Data sesudah tindakan diperoleh dari hasil tes yang diberikan oleh peneliti. Berikut data yang diperoleh selama melakukan penelitian di SMP Mardi Putera Surabaya.

Data sebelum tindakan penelitian diambil dari nilai Ulangan Tengah Semester (UTS) kelas VIII-C SMP Mardi Putera Surabaya. Nilai UTS tersebut digunakan untuk pembentukan kelompok pada siklus 1

Tabel 4.1 Rekapitulasi Nilai UTS Matematika kelas VIII-C

\begin{tabular}{|c|c|c|c|}
\hline \multicolumn{3}{|c|}{ UTS } & \multirow{2}{*}{ Rata-rata } \\
\hline & Jumlah siswa & Prosentase & \\
\cline { 1 - 3 } Tuntas (nilai $\geq 75$ ) & 11 & $44 \%$ & \multirow{2}{*}{68,12} \\
\hline Tidak Tuntas (nilai $<75$ ) & 14 & $56 \%$ & \\
\hline Jumlah & 25 & $100 \%$ & \\
\hline
\end{tabular}

Dari Tabel 4.1 dapat diketahui bahwa siswa yang tuntas sebesar $44 \%$ tuntas dan sebesar $56 \%$ siswa tidak tuntas belajar dengan nilai rata-rata 68,12. 


\section{Data Siklus I}

1. Hasil Belajar Siklus I

Dilihat dari tabel 4.1 menunjukkan bahwa nilai rata-rata siswa sebelum tindakan pembelajaran masih rendah yaitu sebesar 68,12 dan belum mencapai indikator keberhasilan karena kurang dari KKM yang ditentukan. Oleh karena itu, peneliti melakukan penelitian dengan tujuan untuk meningkatkan hasil belajar siswa kelas VIII-C SMP Mardi Putera Surabaya dengan penerapan model pembelajaran Aptitude Treatment Interaction (ATI). Sehingga dapat diperoleh nilai ketuntasan belajar siklus I pada tabel 4.2 di bawah ini.

Tabel 4.2 Rekapitulasi Nilai Matematika Tes I kelas VIII-C

\begin{tabular}{|c|c|c|c|}
\hline \multicolumn{3}{|c|}{ Tes I } & \multirow{2}{*}{ Rata-rata } \\
\cline { 1 - 3 } & Jumlah siswa & Prosentase & \\
\cline { 1 - 3 } Tuntas (nilai $\geq 75$ ) & 20 & $80 \%$ & \multirow{2}{*}{78,44} \\
\cline { 1 - 3 } Tidak Tuntas (nilai $<75$ ) & 5 & $20 \%$ & \\
\hline Jumlah & 25 & $100 \%$ & \\
\hline
\end{tabular}

Tabel 4.2 di atas adalah tabel tes hasil belajar 1 siswa setelah diberikan tindakan pada siklus I. sehingga dapat diketahui bahwa siswa yang tuntas sebesar $80 \%$ dan siswa yang tidak tuntas sebesar $20 \%$ dengan nilai rata-rata sebesar 78,44 .

2. Hasil Pengamatan Aktivitas Siswa

Data hasil pengamatan aktivitas siswa pada siklus I diperoleh ketika pelaksanaan pembelajaran yang di rancang pada RPP 1. Berikut ini adalah hasil pengamatan aktivitas siswa pada siklus I yang disajikan pada Tabel 4.3.

Tabel 4.3

Rekapitulasi rata-rata aktivitas siswa pada pertemuan 1

\begin{tabular}{|c|c|c|c|c|c|c|c|c|c|}
\hline \multirow{3}{*}{ No. } & \multirow{3}{*}{ Nama Kelompok } & \multicolumn{8}{|c|}{ Aktivitas siswa pertemuan $1(\%)$} \\
\hline & & \multicolumn{8}{|c|}{ Kode Aktivitas } \\
\hline & & 1 & 2 & 3 & 4 & 5 & 6 & 7 & 8 \\
\hline 1 & Kelompok Tinggi & 14 & 10 & 8 & 23 & 4 & 1 & 16 & 1 \\
\hline 2 & Kelompok Sedang & 58 & 15 & 8 & 25 & 16 & 16 & 74 & 5 \\
\hline 3 & Kelompok Rendah & 31 & 19 & 8 & 46 & 9 & 3 & 45 & - \\
\hline & Jumlah & 103 & 44 & 24 & 94 & 29 & 20 & 135 & 6 \\
\hline & Rata-rata & 34,33 & 14,67 & 8 & 31,33 & 9,67 & 6,67 & 45 & 2 \\
\hline
\end{tabular}

Kategori kode aktivitas siswa yang diamati

1. Mendengarkan penjelasan guru

2. Bertanya antar siswa dan guru

3. Membaca buku paket 
4. Berdiskusi antar siswa

5. Menyampaikan pendapat

6. Mendengar pendapat teman

7. Mengerjakan Lembar Kerja Siswa

8. Mencatat/merangkum

Dari Tabel 4.3 di atas merupakan frekuensi rata-rata hasil aktivitas siswa selama siklus I. Data pengamatan ini didapatkan dari hasil observasi pada siswa selama proses pembelajaran dengan model pembelajaran aptitude treatment interaction (ATI).

Dari hasil observasi di dapatkan aktivitas siswa yang paling sering dilakukan adalah mengerjakan Lembar Kerja Siswa dengan persentase sebesar 45\%, sedangkan persentase terendah yaitu mencatat/merangkum dengan persentase $2 \%$. Dilihat dari Tabel 4.2 menunjukkan bahwa nilai rata-rata siswa sudah mencapai indikator keberhasilan karena rata-ratanya 77,5. Namun siswa yang tuntas masih belum mencapai $85 \%$ maka peneliti masih ingin meningkatkannya, oleh karena itu peneliti melanjutkan penelitian ke siklus II dengan model pembelajaran aptitude treatment interaction (ATI).

\section{Data Siklus II}

1. Hasil Belajar Siklus II

Data siklus II diperoleh dari proses pembelajaran dengan penerapan model pembelajaran aptitude treatmen interaction (ATI). Data siklus II terlihat pada tabel 4.4 di bawah ini

Tabel 4.4 Rekapitulasi Nilai Matematika Tes II kelas VIII-C

\begin{tabular}{|c|c|c|c|}
\hline \multicolumn{3}{|c|}{ Tes II } & \multirow{2}{*}{ Rata-rata } \\
\cline { 1 - 3 } & Jumlah siswa & Prosentase & \\
\cline { 1 - 2 } Tuntas (nilai $\geq 75$ ) & 22 & $88 \%$ & \multirow{2}{*}{79,25} \\
\hline Tidak Tuntas (nilai $<75$ ) & 3 & $12 \%$ & \\
\hline Jumlah & 25 & $100 \%$ & \\
\hline
\end{tabular}

Tabel diatas adalah tabel tes hasil belajar siswa setelah diberikan tindakan pada siklus II sehingga dapat diketahui bahwa siswa yang tuntas sebesar $88 \%$ tuntas dan sebesar $12 \%$ siswa tidak tuntas belajar dengan nilai rata-rata sebesar 79,25. 
2. Hasil Observasi Aktivitas Siswa

Data observasi aktivitas siswa pada siklus II ini dilakukan dengan menggunakan RPP 2. Berikut hasil observasi aktivitas siswa pada siklus II disajikan pada Tabel 4.5

Tabel 4.5

Rekapitulasi rata-rata aktivitas siswa pada pertemuan 2

\begin{tabular}{|c|c|c|c|c|c|c|c|c|c|}
\hline \multirow{3}{*}{ No } & \multirow{8}{*}{ Nama Kelompok } & \multicolumn{8}{|c|}{ Kode Aktivitas } \\
\cline { 3 - 12 } & & 1 & 2 & 3 & 4 & 5 & 6 & 7 & 8 \\
\hline 1 & Kelompok Tinggi & 57 & 7 & 2 & 30 & 2 & 19 & 60 & 6 \\
\hline 2 & Kelompok Sedang & 20 & 13 & 10 & 6 & 14 & 21 & 63 & 1 \\
\hline 3 & Kelompok Rendah & 10 & 10 & 2 & 18 & 12 & 9 & 15 & - \\
\hline & Jumlah & 87 & 30 & 14 & 54 & 28 & 49 & 138 & 7 \\
\hline & Rata-rata & 29 & 10 & 4,67 & 18 & 9,33 & 16,33 & 46 & 2,33 \\
\hline
\end{tabular}

Tabel 4.5 diatas merupakan rata-rata hasil aktivitas siswa selama siklus II. Data pengamatan ini didapatkan dari hasil observasi pada siswa selama penerapan model pembelajaran aptitude treatment interaction (ATI).

Dari hasil observasi didapatkan aktivitas siswa yang paling sering dilakukan adalah Mengerjakan Lembar Kerja Siswa dengan persentase sebesar $46 \%$ sedangkan persentase terendah adalah mencatat/merangkum yaitu $2,33 \%$

Data hasil angket respon siswa diambil setelah semua siklus dilaksanakan yaitu setelah siklus I dan siklus II hasil angket respon siswa merupakan respon siswa setelah menerapkan model pembelajaran aptitude treatment interaction (ATI).

\section{Pembahasan}

Dalam pembahasan ini akan dijelaskan nilai tes hasil belajar dari siklus I dan siklus II secara rinci, aktivitas siswa selama siklus I dan siklus II.

\section{Siklus I}

Dalam tahap perencanaan, hal-hal yang dilakukan oleh peneliti adalah sebagai berikut:

1. Melakukan Observasi awal

Pada tahap ini peneliti melakukan observasi awal di SMP Mardi Putera

Surabaya untuk menemukan masalah yang dihadapi oleh siswa kelas VIII-C.

2. Menentukan Jadwal Penelitian 
Pada tahap ini peneliti melakukan penentuan jadwal penelitian yang telah disetujui oleh guru kelas dan teman sejawat yakni pada bulan April 2015 minggu ke 1 dan minggu ke 2.

3. Merancang Perangkat Pembelajaran

Pada tahap ini peneliti membuat RPP sesuai dengan Model Pembelajaran Aptitude Treatment Interaction (ATI) Materi Luas Permukaan Kubus. Selanjutnya peneliti membuat Lembar Kerja Siswa (LKS) dan soal tes.

4. Menyiapkan Instrument penelitian untuk menganalisis data

Dalam tahap ini peneliti menyiapkan lembar aktivitas siswa yang digunakan selama proses pembelajaran berlangsung.

5. Mengklasifikasikan kelompok berdasarkan tingkat kemampuannya. (Lampiran 28)

6. Membuat Lembar Observasi aktivitas siswa.

Pelaksanaan kegiatan pembelajaran siklus I dilaksanakan pada tanggal 6 April 2015 dikelas VIII-C dengan 25 siswa. Peneliti melakukan proses pembelajaran sesuai dengan RPP dengan model pembelajaran aptitude treatment interaction (ATI).

Pelaksanaan pada siklus I peneliti bertindak sebagai pengamat. Adapun proses pembelajaran mengacu pada RPP Siklus I yang telah dipersiapkan. Pengamatan dilaksanakan pada saat proses pembelajaran sedang berlangsung. Pengamat I mengamati kelompok rendah, pengamat II mengamati kelompok sedang dan pengamat III mengamati kelompok tinggi. Dari hasil pelaksanaan di dapatkan:

1. Nilai Tes Hasil Belajar

Pada pelaksanaan siklus I dilaksanakan pembelajaran yang terencana pada RPP 1 yang dilaksanakan dalam satu pertemuan dan pada pelaksanaan pembelajaran ini diperoleh rekapitulasi nilai sebelum tindakan dan siklus I pada tabel 4.7 dibawah

Tabel 4.7

Rekapitulasi Nilai UTS dan Siklus I

\begin{tabular}{|c|c|c|c|c|c|}
\hline & $\mathrm{N}$ & $\begin{array}{c}\text { Tuntas } \\
(\text { nilai } \geq 75) \\
(\%)\end{array}$ & $\begin{array}{c}\text { Tidak } \\
\text { Tuntas } \\
(\text { nilai } \leq 75) \\
(\%)\end{array}$ & Rata-rata & $\begin{array}{c}\text { Meningkat } \\
\text { sebesar (\%) }\end{array}$ \\
\hline Nilai UTS & 25 & 44 & 56 & 68,12 & \multirow{2}{*}{15,15} \\
\hline Nilai Siklus I & 25 & 80 & 20 & 78,44 & \\
\hline
\end{tabular}


Pada Tabel 4.7 menunjukkan rekapitulasi nilai matematika sebelum penelitian dan siklus I. Pada data sebelum penelitian berdasarkan Tabel 4.2. dapat dilihat bahwa sebanyak $80 \%$ siswa tuntas belajar dan masih terdapat $20 \%$ siswa tidak tuntas belajar dengan nilai rata-rata 78,44. Dari data sebelum tindakan (lihat tabel 4.1) dengan setelah dilakukan tindakan pada siklus I (lihat tabel 4.2) maka terjadi peningkatan nilai rata-rata sebesar $15,15 \%$. Karena banyaknya siswa yang tuntas pada siklus I belum mencapai $85 \%$ maka dilanjutkan ke siklus II.

\section{Hasil Observasi Aktivitas Siswa}

Pada pelaksanaan siklus I pengamat pertama yaitu Ovy Nuraini mengamati aktivitas siswa pada kelompok rendah, kemudian pengamat kedua Erna Lus Diana mengamati aktivitas kelompok sedang, dan pengamat ketiga Nikie Ramsi Tamnge mengamati aktivitas kelompok tinggi masing-masing tiap 5 menit dalam pembelajaran. Sehingga dalam pengamatan diperoleh frekuensi rata-rata aktivitas siswa pada tabel 4.3 .

Kategori mendengarkan penjelasan guru memiliki rata-rata sebesar 34,33\%, kategori bertanya antar siswa dan guru memiliki rata-rata sebesar 14,67\%, kategori membaca buku paket memiliki rata-rata sebesar $8 \%$, kategori berdiskusi antar siswa memiliki rata-rata sebesar $31,33 \%$, kategori menyampaikan pendapat memiliki rata-rata sebesar 9,67\%, kategori mendengar pendapat teman memiliki rata-rata sebesar $6,67 \%$, kategori mengerjakan lembar kerja siswa memiliki rata-rata sebesar $45 \%$, kategori mencatat/merangkum memiliki rata-rata sebesar 2\%. Dari uraian diatas kategori rata-rata tertinggi yaitu mengerjakan Lembar Kerja Siswa (LKS) memiliki rata-rata $45 \%$ dan kategori terendah yaitu mencatat/merangkum dengan rata-rata $2 \%$.

\section{Refleksi}

1. Berdasarkan tes hasil belajar pada siklus I, nilai rata-rata siswa yang dicapai adalah 78,44 dan telah mencapai KKM yaitu $\geq 75$. Siswa yang tuntas belajarnya sebesar $80 \%$ sedangkan sebesar $20 \%$ tidak tuntas belajar.

2. Terdapat beberapa kekurangan pada siklus I antara lain: 
a. Siswa cenderung lebih banyak mendengarkan penjelasan guru

b. Masih ada beberapa siswa dikelompok sedang dan rendah yang masih belum aktif dalam pembelajaran

Karena banyaknya siswa yang tuntas belajar pada siklus I belum mencapai 85\%, dan masih terdapat kekurangan pada pembelajaran siklus I sehingga diperlukan adanya suatu tindakan pada siklus II agar hasil belajar siswa dapat mencapai indikator keberhasilan.

\section{Siklus II}

Berdasarkan hasil refleksi pada siklus I yang belum mencapai indikator keberhasilan maka peneliti melakukan perencanaan pada siklus II agar pemebelajaran lebih efektif dan indikator keberhasilan dapat tercapai. Dalam tahap perencanaan, hal-hal yang dilakukan oleh peneliti adalah sebagai berikut:

1. Merancang Perangkat Pembelajaran

Pada tahap ini peneliti membuat RPP Materi Luas Permukaan Kubus. Selanjutnya peneliti membuat Lembar Kerja Siswa (LKS) dan soal tes.

2. Menyiapkan Instrument penelitian untuk menganalisis data

Dalam tahap ini peneliti menyiapkan lembar aktivitas siswa yang digunakan selama proses pembelajaran berlangsung.

3. Mengklasifikasikan kelompok berdasarkan tingkat kemampuannya. (Lampiran 29)

Pelaksanaan kegiatan pembelajaran untuk siklus II dilaksanakan pada tanggal 16 April 2015 dikelas VIII-C dengan 25 siswa. Peneliti melakukan proses pembelajaran sesuai dengan RPP dengan model pembelajaran aptitude treatment interaction (ATI). Dari hasil pelaksanaan di dapatkan:

1. Nilai Tes Hasil Belajar

Pada pelaksanaan siklus II dilaksanakan pembelajaran yang terencana pada RPP 2 dalam satu pertemuan. Data nilai siklus I dan nilai siklus II jika dibandingkan diperoleh data pada tebel 4.8 . 


\section{Tabel 4.8}

Rekapitulasi Nilai matematika Siklus I dan Siklus II

\begin{tabular}{|c|c|c|c|c|c|}
\hline & $\mathrm{N}$ & $\begin{array}{c}\text { Tuntas } \\
(\text { nilai } \geq 75) \\
(\%)\end{array}$ & $\begin{array}{c}\text { Tidak Tuntas } \\
(\text { nilai } \leq 75) \\
(\%)\end{array}$ & Rata-rata & $\begin{array}{c}\text { Meningkat } \\
\text { sebesar (\%) }\end{array}$ \\
\hline Nilai Siklus I & 25 & 80 & 20 & 78.44 & \multirow{2}{*}{1,03} \\
\hline Nilai Siklus II & 25 & 88 & 12 & 79.25 & \\
\hline
\end{tabular}

Pada Tabel 4.8 menunjukkan rekapitulasi hasil tes nilai siswa pada siklus I dan II. Pada Tabel 4.4 dapat dilihat bahwa sebanyak $88 \%$ siswa tuntas belajar dan masih terdapat $20 \%$ siswa yang tidak tuntas belajar dengan rata-rata 79,25 ini menunjukkan adanya peningkatan terhadap hasil belajar siswa dari siklus I ke siklus II yaitu sebesar $1,03 \%$ dan nilai rata-rata siswa sudah mencapai indikator keberhasilan yang telah ditentukan.

2. Hasil observasi aktivitas siswa

Pada siklus II pengamat pertama mengamati kelompok sedang dan rendah sedangkan pengamat kedua mengamati kelompok tinggi pengamatan dilakukan setiap 5 menit. Sehingga dalam pengamatan pada siklus II diperoleh rata-rata aktivitas siswa pada Tabel 4.5

Kategori mendengarkan penjelasan guru memiliki rata-rata sebesar 29\%, kategori bertanya antar siswa dan guru memiliki rata-rata sebesar 10\%, kategori membaca buku paket memiliki rata-rata sebesar 4,67\%, kategori berdiskusi antar siswa 18\%, kategori menyampaikan pendapat 19,33\%, kategori mendengar pendapat teman memiliki rata-rata sebesar $16,33 \%$, kategori mengerjakan Lembar Kerja Siswa memiliki rata-rata sebesar 46\%, kategori mencatat/merangkum 2,33\%. Dari uraian diatas kategori rata-rata tertinggi yaitu mengerjakan Lembar Kerja Siswa (LKS) memiliki rata-rata $46 \%$ dan kategori terendah yaitu mencatat/merangkum dengan rata-rata $2,33 \%$.

\section{Refleksi}

Berdasarkan hasil belajar pada siklus II. Nilai rata-rata yang dicapai adalah 79,25 dan telah mencapai $\mathrm{KKM}$ yang ditentukan yaitu $\geq 75$. Siswa yang tuntas 


\section{Ovy Nuraini', Chusnal Ainy ${ }^{2}$, Endang Suprapti ${ }^{3}$}

belajarnya sebesar $88 \%$. Dan kekurangan yang terdapat pada siklus I sudah dapat diatasi. Dari hasil evaluasi siklus II ini siswa sudah mencapai indikator keberhasilan yang telah ditentukan oleh sekolah SMP Mardi Putera Surabaya.

\section{Hasil Angket Siswa}

Dari hasil kuesioner diperoleh data hasil yang diberikan siswa terlihat bahwa 93.5\% siswa mampu merespon dengan baik. Hasil ini dapat dilihat pada uraian dibawah ini.

Berdasarkan tabel 4.6 hasil angket dari 25 siswa kelas VIII-C SMP Mardi Putera Surabaya dengan 8 pertanyaan adalah:

1. Sebanyak 25 siswa dengan persentase $100 \%$ yang setuju sedangkan $0 \%$ tidak setuju bahwa kegiatan pembelajaran yang menerapkan model pembelajaran aptitude treatment interaction (ATI) merupakan suatu hal yang baru bagi mereka.

2. Sebanyak 24 siswa dengan persentase $96 \%$ yang setuju sedangkan 1 siswa dengan persentase $4 \%$ tidak setuju bahwa penerapan model pembelajaran aptitude treatment interaction (ATI) menyenangkan dalam proses pembelajaran yang diikuti.

3. Sebanyak 23 siswa dengan persentase $92 \%$ yang setuju sedangkan 2 siswa dengan persentase $8 \%$ tidak setuju bahwa penerapan model pembelajaran aptitude treatment interaction (ATI) dapat membangun proses belajar yang baik.

4. Sebanyak 22 siswa dengan persentase $88 \%$ yang setuju sedangkan 3 siswa dengan persentase $12 \%$ tidak setuju bahwa penerapan model pembelajaran aptitude treatment interaction (ATI) mudah dipahami.

5. Sebanyak 24 siswa dengan persentase $96 \%$ yang setuju sedangkan 1 siswa dengan persentase $4 \%$ tidak setuju bahwa penerapan model aptitude treatment interaction (ATI) yang diterapkan guru dapat memudahkan siswa memahami materi kubus dan balok.

6. Sebanyak 24 siswa dengan persentase $96 \%$ yang setuju sedangkan 1 siswa dengan persentase $4 \%$ tidak setuju bahwa penerapan model pembelajaran 
aptitude treatment interaction (ATI) dapat memudahkan siswa dalam menyelesaikan soal tes yang diberikan.

7. Sebanyak 24 siswa dengan persentase $96 \%$ yang setuju sedangkan 1 siswa dengan persentase $4 \%$ tidak setuju bahwa penerapan model pembelajaran aptitude treatment interaction (ATI) dapat memudahkan siswa dalam memahami pelajaran matematika.

8. Sebanyak 21 siswa dengan persentase $84 \%$ setuju sedangkan 4 siswa dengan persentase $16 \%$ tidak setuju bahwa penerapan model pembelajaran aptitude treatment interaction (ATI) boleh diterapkan pada materi lain.

Dari hasil kuesioner diatas persentase tertinggi yaitu pada penerapan model pembelajaran aptitude treatment interaction (ATI) merupakan hal yang baru yaitu 25 siswa dengan persentase $100 \%$ yang setuju.

\section{SIMPULAN}

Berdasarkan hasil dan analisis data serta pembahasan pada bab IV maka dapat diambil simpulan sebagai berikut:

1. Penerapan Model Pembelajaran Aptitude Treatment Interaction (ATI) pada pelajaran matematika di SMP Mardi Putera Surabaya Memperoleh Hasil yang Baik. Hal ini ditunjukkan dari:

a. Aktivitas siswa pada siklus I dan siklus II yang memperoleh persentase tertinggi adalah kategori mengerjakan Lembar Kerja Siswa Dengan persentase sebesar $45 \%$ pada siklus I dan persentase sebesar $46 \%$ pada siklus II.

b. Siswa kelas VIII-C SMP Mardi Putera Surabaya merespon sangat baik setelah penerapan model pembelajaran aptitude treatment interaction (ATI) terbukti dari angket siswa.

2. Hasil belajar matematika siswa kelas VIII-C SMP Mardi Putera Surabaya dapat ditingkatkan dengan menggunakan model pembelajaran aptitude treatment interaction (ATI). Hal ini dapat dilihat dari nilai UTS sebelum penelitian ke siklus I yang memperoleh rata-rata 78,44 atau meningkat sebesar $15,15 \%$ dan 
dari nilai siklus I ke siklus II yang memperoleh rata-rata 79,25 atau meningkat sebesar $1,03 \%$. Dengan demikian penerapan model pembelajaran aptitude treatment interaction (ATI) dapat meningkatkan hasil belajar matematika siswa kelas VIII-C SMP Mardi Putera Surabaya.

\section{DAFTAR PUSTAKA}

Aga, Nur Azizah Eka Fitria Permatasari. 2014. "Pengaruh Model Pembelajaran Aptitude Treatment Interaction (ATI) Terhadap Hasil Belajar Matematika Siswa Pada Materi Bangun Ruang Kelas VIII SMP Negeri 2 Sendang Tulungagung Semester Genap Tahun Ajaran 2012/2013”. [Skripsi] (online). Diakses dari: http://repo.iain-tulungagung.ac.id/413/ Juli, 29, 2015

Amri, Sofan. 2013. Pengembangan \& Model Pembelajaran dalam Kurikulum 2013. Jakarta : PT. Prestasi Pustakarya.

Arikunto, Suharsimi. 2012. Dasar-dasar Evaluasi Pendidikan Edisi 2. Jakarta: Bumi Aksara

Dahar, Ratna Wilis.2011. Teori-teori Belajar dan Pembelajaran. Jakarta : Erlangga.

Ernawati, Eka. 2007. Penerapan Pembelajaran Matematika Realistik Pokok Bahasan Volum Bangun Ruang kelas V SD Muhammadiyah Sedayu tahun 2007. (skripsi tidak dipublikasikan). Surabaya: Universitas Muhammadiyah Surabaya.

Hasanah, Roini Uswatun. 2011. Upaya Meningkatkan Prestasi Belajar Matematika dengan Menggunakan Model Pembelajaran Aptitude Treatment Interaction (ATI) pada siswa kelas VII E SMPN 45 Surabaya tahun ajaran 2010-2011. (skripsi tidak dipublikasikan). Surabaya: Universitas Muhammadiyah Surabaya.

Hanafiah, Nanang dan Cucu Suhana. 2009. Konsep Strategi Pembelajaran. Bandung: PT Refika Aditama.

http://nasional.sindonews.com/read/804091/15/pembelajaran-matematika-diindonesia-masuk-peringkat-rendah-1384111047 diakses pada tgl 31 januari 2015 pukul 14.22

http://www.wartamadani.com/2013/05/konsep-pembelajaran-ati-aptitude.html diakses pada tgl 16 februari 2015 pukul 10.15

Kurniawan, Deni. 2011. Pembelajaran Terpadu:Teori,Praktik dan Penilaian. Bandung : CV. Pustaka Cendikia Utama.

Mendikbud. 2014. Matematika Kelas VIII SMP/MTS Semester 2. Jakarta : pusat Kurikulum dan Perbukuan, Balitbang.

Mulyasa, H. E. 2011. Praktik Penelitian Tindakan Kelas. Bandung: PT Remaja Rosdakarya Offset.

Pribadi, Benny A. 2011. Model Desain Sistem Pembelajaran. Jakarta: PT. Dian Rakyat

Rusman. 2012. Model-Model Pembelajaran Mengembangkan Profesionalisme Guru. Jakarta: PT Raja Grafindo Persada. 

Belajar

Syarifuddin, Achmad. 2013. Meningkatkan Hasil Belajar Matematika Materi Menghitung Volume Balok dan Kubus dengan Penggunaan Media Kubus satuan pada siswa kelas V SD Muhammadiyah 3 Surabaya. (skripsi tidak dipublikasikan). Surabaya: Universitas Muhammadiyah Surabaya.

Undang-Undang Republik Indonesia Nomor 20 Tahun 2003. Sistem Pendidikan Nasional. 